Teresa Villaescusa ${ }^{1}$

Lourdes Vázquez ${ }^{2}$

Juan Miguel Bergua ${ }^{3}$

Julio Garcia ${ }^{4}$

Antonio Romero ${ }^{5}$

M. Teresa Olave ${ }^{6}$

Daniel Garcia Belmonte ${ }^{7}$

M. Paz Queipo de Llano ${ }^{8}$

Grupo de Infecciones en

pacientes hematológicos.

Sociedad Andaluza

de Hematología y

Hemoterapia.

\section{Micafungin as antifungal prophylaxis in non-transplanted haemotological patients}

${ }^{1}$ Hospital Virgen de la Concha, Zamora.

${ }^{2}$ Hospital Clínico Universitario, Salamanca.

${ }^{3}$ Hospital San Pedro de Alcántara, Cáceres.

${ }^{4}$ Hospital Universitario Príncipe de Asturias, Madrid.

${ }^{5}$ Complejo Hospitalario Universitario, Granada.

${ }^{6}$ Hospital Clínico Lozano Blesa, Zaragoza.

${ }^{7}$ Hospital Universitario de La Zarzuela, Madrid.

${ }^{8}$ Hospital Virgen de la Victoria, Málaga.

\section{Article history}

Received: 10 September 2019; Revision Requested: 29 0ctober 2019; Revision Received: 23 November 2019;

Accepted: 25 November 2019; Published: 23 December 2019

\section{ABSTRACT}

Introduction. Fungal infections are a major cause of morbidity and mortality in the haematological patients. These infections are mainly due to Candida spp. and Aspergillus spp. Mortality by these infections is high, but rates have descended in the latest series due to better antifungal agents. Echinocandins are, in vitro, very active against Candida and Aspergillus spp. The objective of the study is to analyse the efficacy and safety of micafungin in the antifungal prophylaxis of haematological patients on chemotherapy.

Material and methods. A multicentre, observational retrospective study was performed in 7 Haematology Departments in Spain. Patients admitted to these departments with chemotherapy or immunosuppressive treatment, and who had received antifungal prophylaxis with micafungin between 1 January 2009 and 31 December 2014 were included.

Results. There were 5 cases of probable or proven fungal infection (4.8\%) according to the 2008 EORTC criteria: 2 proven, 3 probable. The types of fungal infection were 3 aspergillosis and 2 candidiasis. There were no drop-outs from the prophylaxis with micafungin due to toxicity.

Conclusion. Micafungin is an antifungal agent which, used in prophylaxis, has demonstrated good efficacy and an excellent toxicity profile, making it an apparently interesting option in patients requiring antifungal prophylaxis during their hospitalisation episode.

Key words: fungal, Aspergilllus, prophylaxis, toxicity, echinocandins.

Correspondence:

Teresa Villaescusa de la Rosa.

Hospital Virgen de la Concha. Avda. Requejo n 35. 49022. Zamora.

E-mail: tvillaescusa@saludcastillayleon.es

\section{Micafungina como profilaxis antifúngica en pacientes hematológicos no trasplantados}

\section{RESUMEN}

Introducción. Las infecciones fúngicas son una importante causa de morbilidad y mortalidad en los pacientes hematológicos. Estas infecciones son principalmente debidas a Candida spp.y Aspergillus spp. La mortalidad debida a estas infecciones es alta, pero ha descendido a lo largo de las últimas series gracias a los mejores agentes antifúngicos. Las equinocandinas son, in vitro, muy activas contra Candida y Aspergillus spp. El objetivo de este estudio es analizar la eficacia y seguridad de micafungina en la profilaxis antifúngica de pacientes hematológicos en tratamiento quimioterápico.

Material y métodos. Un estudio multicéntrico, observacional, retrospectivo se llevó a cabo en 7 servicios de Hematología en España. Se incluyeron los pacientes ingresados con quimioterapia o tratamiento inmunosupresor que hubieran recibido micafunfina como profilaxis entre el 1 de enero de 2009 y el 31 de diciembre de 2014.

Resultados. Hubo 5 casos de infección fúngica probable o probada $(4,8 \%)$ según los criterios de la EORTC de 2008: 2 probadas, 3 probables. Las infecciones fúngicas fueron 3 aspergilosis y 2 candidiasis. No hubo ningún abandono de la profilaxis con micafungina debido a toxicidad.

Conclusión. Micafungina es un agente antifúngico que, usado en profilaxis, ha demostrado buena eficacia y excelente perfil de toxicidad, siendo una opción interesante en pacientes que requieren profilaxis antifúngica durante su hospitalización. 


\section{INTRODUCTION}

Fungal infections are a major cause of morbidity and mortality in haematological patients, particularly in at high risk of fungal infection patients $[1,2]$. The increase in the number of individuals with some type of immunosuppression, is the most important cause in the increase of this type of infections. Approximately $10 \%-50 \%$ of haematological patients with marked neutropenia or recipients of a haematopoietic stem cell transplant have an episode of Invasive Fungal Infection (IFI) during the evolution of their disease. These infections are mainly due to Candida spp. and Aspergillus spp. [2-4]. Mortality by these infections is usually high, due to the difficulty involved in making an early diagnosis. Fortunately, mortality rates for aspergillosis have gradually descended in the latest series and this is fundamentally due to two important breakthroughs. On the one hand, the improvement in early diagnostic techniques, such as galactomannan, aspergillus PCR and imaging techniques. On the other hand, the advent of antifungal agents with greater efficacy and good tolerance used for prophylactic, empirical, pre-emptive and targeted treatment $[5,6]$. Echinocandins are very active in vitro against Candida and Aspergillus spp. [7], which have proven their efficacy in the prophylaxis of fungal infection [8]. Micafungin, as opposed to the other echinocandins, presents a better activity against certain strains of Candida spp., classically Candida glabrata [7, 9] and also against Aspergillus spp. [8, 10]. It has a low potential for drug interactions [11-14], which could make it interesting in the case of patients requiring concomitant medication and it can be given to patients with moderate liver failure in whom the azoles, the reference drugs in prophylaxis, have certain limitations [15]. This is why there are consensus-based documents that point to the advantages of this drug in prophylaxis [16]. There is published experience with micafungin in the primary prophylaxis of haematological patients in the context of haematopoietic stem cell transplant and acute myeloid leukaemias induction therapy $[17,18]$. International guidelines provide a recommendation for micafungin, both in prophylaxis and in the treatment of the candidiasis $[4,19-21]$

Some Spanish centres have accumulated experience in primary prophylaxis with micafungin in patients admitted to haematology departments undergoing chemotherapy in whom a prolonged period of neutropenia is expected and in whom azoles might constitute a problem of tolerability due to drug interactions, liver alterations, long OT syndrome or intolerance. There is a great deal of experience published with micafungin in the antifungal prophylaxis of patients undergoing haematopoietic stem cell transplant [22-26]. However, experience is more limited in non-transplanted patients. Therefore, the evaluation of the efficacy and safety of antifungal prophylaxis with micafungin in haematological patients undergoing chemotherapy is an interesting area of investigation, and therefore we are proposing a retrospective analysis of patients undergoing chemotherapy who have received prophylactic antifungal treatment with micafungin. The objective of the study is to analyse the efficacy and safety of micafungin in the anti- fungal prophylaxis of haematological patients on chemotherapy.

\section{MATERIAL AND METHODS}

A multicentre, observational retrospective study was performed in 7 Haematology Departments in Spain. All the patients admitted to these departments that had received chemotherapy or immunosuppressive treatment for their haematological disease and who had received antifungal prophylaxis with micafungin over 5 consecutive days in the period comprised between 1 January 2009 and 31 December 2014 were included. Each patient's observation period ended when they were discharged for any reason. Micafungin was administered intravenously at a dose of $50 \mathrm{mg}$ a day.

The data were obtained from the patients' health history by means of a case report form (CRF) requested from the Alce Ingenieria company, whereas the SPSS statistical application was used for the statistical analysis.

The possible, probable or proven fungal infection criteria were consistent with those described by the Invasive Fungal Infections Cooperative Group of the European Organization for Research and Treatment of Cancer (EORTC) of 2008 [27].

The objective was to analyse the efficacy and safety of micafungin in the antifungal prophylaxis of haematological patients on chemotherapy. The efficacy of antifungal prophylaxis was defined as the absence of diagnosed or suspected fungal infection during the prophylaxis period with micafungin. For this purpose, the daily dose used, the days of prophylaxis, the reason for the end of treatment, the need to change the anti-fungal agent or the dose of micafungin, the reasons for the change, as well as the results of the different diagnostic tests performed such as cultures, serologies or radiological tests, were analysed. With regard to safety, micafungin's tolerability and safety were analysed on the basis of adverse reactions recorded in the medical history as being attributable to the treatment with micafungin, as well as the degree of the adverse reaction.

\section{RESULTS}

A total of 104 episodes corresponding to 89 haematological patients from 7 hospitals in Spain were analysed. The patients' baseline characteristics can be observed in table 1. The median patient age was 59 years (range 19-84), 55 were men and 34 were woman. The patients presented the following haematological diseases: Forty-three episodes of acute myeloid leukaemia (41.3\%), thirty-one episodes of acute lymphoblastic leukaemia $(29.8 \%)$, ten episodes of lymphoma (9.6\%), nine episodes of aplastic anemia (8.7\%) and eleven episodes of other haematological conditions (10.6\%). The median of days of hospitalisation for the episodes was 31.5 days. In 63 episodes reported $(60.6 \%)$, micafungin was given as prophylaxis following the diagnosis. It should be emphasised that in $19 \mathrm{ep}-$ isodes $(18.3 \%)$, the patients were in relapse, partial response 


\begin{tabular}{|c|c|}
\hline Table 1 & $\begin{array}{l}\text { Patients' baseline and } \\
\text { demographic characteristics }\end{array}$ \\
\hline \multicolumn{2}{|c|}{ Age [median (range)]: 59 years ( $19-84$ years) } \\
\hline \multicolumn{2}{|l|}{ Sex } \\
\hline \multicolumn{2}{|c|}{ Male: 55 patients (61.8\%) } \\
\hline \multicolumn{2}{|c|}{ Female: 34 patients (38.2\%) } \\
\hline \multicolumn{2}{|c|}{ Haematological disease } \\
\hline \multicolumn{2}{|c|}{ Acute myeloblastic leukaemia: 43 episodes (41.3\%) } \\
\hline \multicolumn{2}{|c|}{ Acute lymphoblastic leukaemia: 31 episodes (29.8\%) } \\
\hline \multicolumn{2}{|c|}{ Lymphoma: 10 episodes (9.6\%) } \\
\hline \multicolumn{2}{|c|}{ Bone marrow aplasia: 9 episodes (8.7\%) } \\
\hline \multicolumn{2}{|c|}{ Others: 11 episodes $(10.6 \%)$} \\
\hline \multicolumn{2}{|c|}{ Situation of the disease } \\
\hline \multicolumn{2}{|c|}{ Diagnosis: 63 patients $(60.6 \%)$} \\
\hline \multicolumn{2}{|c|}{ Complete remission: 20 patients (19.2\%) } \\
\hline \multicolumn{2}{|c|}{ Partial response: 7 patients $(6.7 \%)$} \\
\hline \multicolumn{2}{|c|}{ Relapse: 11 patients (10.6\%) } \\
\hline \multicolumn{2}{|c|}{ Salvage: 0 patients $(0 \%)$} \\
\hline \multicolumn{2}{|c|}{ Resistant: 1 patient (1\%) } \\
\hline \multicolumn{2}{|c|}{ Unknown: 2 patients $(1.2 \%)$} \\
\hline \multicolumn{2}{|c|}{ Total: 104 episodes } \\
\hline \multicolumn{2}{|c|}{ Days' hospitalisation: 31.5 days (range 4-451) } \\
\hline
\end{tabular}

or resistant; in other words, with uncontrolled haematological disease.

In most of the episodes (95) micafungin was the selected drug as prophylaxis because of the center practice. Some of the other reasons for the choice were drug interactions with the use of other antifungals (4), liver dysfunctions (15), severe mucositis (7) or long OT syndrome (1). The results are displayed in greater detail in table 2.

The median days of use of micafungin was 18 days (range 5-384) at a dose of $50 \mathrm{mg} /$ day. We have data from 101 of the 104 episodes with regard to the reason for the end of prophylaxis. There were no drop-outs from the prophylaxis with micafungin due to toxicity, and the prophylaxis was finished when the neutropenia period ended in $64.4 \%$ of the cases. Empirical antifungal treatment was initiated in 19 episodes (18.8\%), the antifungal was changed on 7 occasions, and in 10 cases the prophylaxis was finished for other reasons. The data are shown in table 3. 91 of the 104 episodes (87.5\%) presented neutropenia $\left(<500\right.$ neutrophils $\left./ \mathrm{mm}^{3}\right)$, with a median duration of 22 days. There were 59 episodes of fever (56.7\%) and 45 episodes (43.3\%) without fever during hospitalisation. There were 5 cases of probable or proven fungal infection (4.8\%) according to the 2008 EORTC criteria: 2 proven and 3 probable. We have eliminated 4 possible fungal infections because probably there are not an IFI. The types of fungal infection were 3

\begin{tabular}{l|l}
\hline Table 2 & $\begin{array}{l}\text { Reasons for the use of micafungin. } \\
\text { (More than one reason could be } \\
\text { chosen). }\end{array}$ \\
\hline Prophylaxis & 95 \\
Protocol & 13 \\
Failure of previous antifungal & 2 \\
Limiting drug interactions & 4 \\
Liver dysfunctions & 15 \\
Severe mucositis & 7 \\
Long QT syndrome & 1 \\
Other reason & 31 \\
\hline
\end{tabular}

\begin{tabular}{l|c}
\hline Table 3 & $\begin{array}{l}\text { Reasons for ending prophylaxis } \\
\text { with micafungin in } 101 \text { of the } 104 \\
\text { total episodes. }\end{array}$ \\
\hline End of prophylaxis & $65(64.4 \%)$ \\
Adverse reaction & $0(0 \%)$ \\
Empirical treatment & $19(18.8)$ \\
Change of antifungal & $7(6.9 \%)$ \\
Other & $10(9.9 \%)$ \\
Total & 101 evaluable episodes \\
\hline
\end{tabular}

\begin{tabular}{l|l} 
Table 4 & Development of fungal infection
\end{tabular}

\begin{tabular}{lc} 
Probable or proven fungal infection & \\
NO & 99 episodes $(95.2 \%)$ \\
YES & 5 episodes $(4.8 \%)$ \\
Total & 104 episodes \\
EORTC criteria & \\
Probable & $3(60 \%)$ \\
Proven & $2(40 \%)$ \\
\hline
\end{tabular}

EORTC : European Organization for Research and Treatment of Cancer

probable aspergillosis and 2 proven candidiasis. The data are shown in table 4 . Of the 26 patients that needed to start empirical antifungal treatment or a change of antifungal, probable or proven fungal infection according to the EORTC criteria was only confirmed in 5 cases (19.2\%). In other words, 80,8\% of the patients who were switched from micafungin to other antifungals did not ultimately develop an IFI. Twelve (11.7\%) of the 89 patients recruited to the study died, although only 2 of them were diagnosed with fungal infection. 88.3\% of the cases were discharged due to clinical improvement. 


\section{DISCUSSION}

Fungal infections are a serious complication in haematological patients and are associated with a high rate of mortality. One of the most commonly used strategies is prophylaxis in patients at risk. The azoles are the drugs that have been used most in prophylaxis in haematological patients. However, we know that they have a toxicity profile that renders them incompatible with other drugs or the patients' clinical situations. For this purpose, other families of drugs that may be used in prophylaxis are needed. Of all the requirements that a prophylactic drug must meet, one of the most important ones is good efficacy, but the drugs must be safe and easy to administer. Micafungin is an agent that is widely used in the haematological population for the prevention of IFI. There are works involving prophylaxis with micafungin in homogeneous populations of patients, such as in acute induction leukaemias. It has been compared to posaconazole in patients with acute leukaemias and myelodysplastic syndromes on induction treatment in a randomised study, proving to be a safe prophylactic alternative in this type of patients [28]. It has also been compared to fluconazole and traconozole in patients undergoing haploidentical transplantation, presenting good efficacy [29]. We also have data from a meta-analysis performed with 1,049 cases and 959 controls, confirming that micafungin had a significantly higher treatment success rate than the other antifungals, with a better secure profile [30]. However, there are no published data with more heterogeneous patient populations in real practice. This study shows one of the largest populations studied to date on prophylaxis with micafungin. The incidence of probable or proven invasive fungal infection in our study population is 4,8\%, similar to that which is published in other series [2-4], particularly considering that a large part of the population of our study were highrisk patients diagnosed with acute leukaemias. In most of these cases, the causal agent was Aspergillus spp, although none of the proven IFI were caused by this fungus, but rather by Candida spp. With regard to drug safety, it was a drug with an excellent toxicity profile that did not require any withdrawals due to toxicity. What is more, in some cases it was the drug of choice after toxicity by previous prophylaxis.

This study has important limitations, particularly on account of its retrospective nature. Similarly, the patients are very heterogeneous, although we consider this to be part of our hospitals' daily practice. New prospective studies in different haematological populations would be very interesting in order to confirm these data.

\section{FUNDING}

This work was supported by an unrestricted grant from Astellas Pharma S.A. (Madrid, Spain). The funder had no role in the study design, data collection and interpretation, or the decision to submit the work for publication.

\section{CONFLICT OF INTEREST}

None to declare

\section{REFERENCES}

1. Tacke D, Buchheidt D, Karthaus $M$, Maschmeyer G, Neumann S, Ostermann $\mathrm{H}$ et al. Primary prophylaxis of invasive fungal infections in patients with haematologic malignancies. 2014 update of the recommendations of the infectious diseases working party of the German Society for Haematology and Oncology. Ann Hematol. 2014; 93(9):1449-56. DOI: 10.1007/s00277-014-2108-y

2. Akan $H$, Antia VP, Kouba $M$, Sinkó J, Tănase $A D, V$ rhovac $R$ et al. Preventing invasive fungal disease in patients with haematological malignancies and the recipients of haematopoietic stem cell transplantation: practical aspects. J Antimicrob Chemother 2013;68 suppl 3:III5-16. DOI:10.1093/jac/dkt389

3. Marr KA, Carter RA, Crippa F, Wald A, Corey L. Epidemiology and outcome of mould infections in hematopoietic stem cell transplant recipients. Clin Infect Dis. 2002 Apr 1;34(7):909-17. DOI:10.1086/339202

4. Ullmann AJ, Akova M, Herbrecht R, Viscoli C, Arendrup MC, Arikan-Akdagli $S$, et al. ESCMID* guideline for the diagnosis and management of Candida diseases 2012: adults with haematological malignancies and after haematopoietic stem cell transplantation (HCT). Clin Microbiol Infect. 2012;18 Suppl 7:53-67. DOI:10.1111/1469-0691.12041

5. Upton A, Kirby KA, Carpenter P, Boeckh M, Marr KA. Invasive aspergillosis following hematopoietic cell transplantation: outcomes and prognostic factors associated with mortality. Clin Infect Dis. 2007; 44(4):531-40. DOI:10.1086/510592

6. Herbrecht $R$, Denning DW, Patterson TF, Bennett JE, Greene RE, Oestmann JW, et al. Voriconazole versus amphotericin B for primary therapy of invasive aspergillosis. N Engl J Med. 2002 Aug 8;347(6):408-15. DOI:10.1056/NEJMoa020191

7. Pfaller MA, Diekema DJ, Ostrosky-Zeichner L, Rex JH, Alexander BD, Andes D et al. Correlation of MIC with outcome for Candida species tested against caspofungin, anidulafungin, and micafungin: analysis and proposal for interpretive MIC breakpoints. J Clin Microbiol. 2008; 46(8):2620-9. DOI:10.1128/JCM.00566-08

8. Wiederhold, NP, Cota J, Frei CR. Micafungin in the treatment of invasive candidiasis and invasive aspergillosis. Infect Drug Resist. 2008; 1: 63-77. PMID:21694882

9. Dannaoui E, Lortholary O, Raoux D, Bougnoux ME, Galeazzi G, Lawrence $C_{1}$ et al. Comparative in vitro activities of caspofungin and micafungin, determined using the method of the European Committee on Antimicrobial Susceptibility Testing, against yeast isolates obtained in France in 2005-2006. Antimicrob Agents Chemother. 2008; 52(2):778-81. D0I:10.1128/AAC.01140-07

10. Espinel-Ingroff A. In vitro antifungal activities of anidulafungin and micafungin, licensed agents and the investigational triazole posaconazole as determined by NCCLS methods for 12,052 fungal isolates: review of the literature. Rev Iberoam Micol. 2003;20(4):121-36. PMID:15456349

11. Undre NA, Stevenson P, Wilbraham D. Pharmacokinetic profile of micafungin when co-administered with amphotericin B in healthy male subjects. Int J Clin Pharmacol Ther. 2014; 52(3):237-44. D0I: 10.5414/CP202015 
12. Summary of Product Characteristics of MYCAMINE ${ }^{\circledR}$ (micafungin sodium) for injection. Astellas Pharma Europe Ltd. (Accesed 9 September 2019) https://www.ema.europa.eu/en/documents/product-information/mycamine-epar-product-information_en.pdf

13. Eschenauer G, Depestel DD, Carver PL. Comparison of echinocandin antifungals. Ther Clin Risk Manag. 2007; 3(1): 71-97. D0I:10.2147/ tcrm.2007.3.1.71

14. Keirns J, Sawamoto T, Holum M, M, Buell D, Wisemandle W, Alak A. Steady-state pharmacokinetics of micafungin and voriconazole after separate and concomitant dosing in healthy adults. Antimicrob Agents Chemother 2007; 51:787, 787-90. D0I:10.1128/ AAC.00673-06

15. Vehreschild MJ, von Bergwelt-Baildon M, Tran L, Shimabukuro-Vornhagen $A$, Wisplinghoff $H$, Bangard $C$ et al. Feasibility and effectiveness of posaconazole prophylaxis in combination with micafungin bridging for patients undergoing allogeneic stem cell transplantation: A 6-yr analysis from the cologne cohort for neutropenic patients. Eur J Haematol. 2014; 93(5): 400-6. DOI: 10.1111/ejh.12368.

16. Vázquez López L, Villaescusa de la Rosa $T$, De La Cámara R, Espigado I, Grau Cerrato S, Jurado $M$, et al. Posicionamiento y actitudes de manejo sobre la profilaxis antifúngica en el paciente hematológico (proyecto PROMIC). Rev Esp Quimioter. 2017;30(3):21323. PMID:28537063

17. Park HJ, Park M, Han M, Nam BH, Koh KN, Im HJ, et al. Efficacy and safety of micafungin for the prophylaxis of invasive fungal infection during neutropenia in children and adolescents undergoing allogeneic hematopoietic SCT. Bone Marrow Transplant. 2014; 49(9):1212-6. DOI:10.1038/bmt.2014.136

18. Venton G, Adam H, Colle J, Labiad Y, Mercier C, Ivanov V, et al. Micafungin as primary antifungal prophylaxis in patients presenting with acute myeloid leukemia. Med Mal Infect. 2016;46(4):226-9. D0I:10.1016/j.medmal.2016.03.008

19. Maertens JA, Girmenia C, Bruggemann RJ, Duarte RF, Kibbler CC, Ljungman $P_{\text {, et }}$ al. European guidelines for primary antifungal prophylaxis in adult haematology patients: summary of the updated recommendations from the European Conference on Infections in Leukaemia. J Antimicrob Chemother. 2018;73(12):3221-30. DOI:10.1093/jac/dky286

20. Hope WW, Castagnola E, Groll, AH Roilides E, Akova M, Arendrup $\mathrm{MC}$ et al. ESCMID* guideline for the diagnosis and management of Candida diseases 2012: prevention and management of invasive infections in neonates and children caused by Candida spp. Clin Microbiol Infect. 2012; 18 Suppl 7:38-52. DOI: 10.1111/14690691.12040

21. Groll AH, Castagnola E, Cesaro S, Dalle JH, Engelhard D, Hope W et al. Fourth european conference on infections in leukaemia (Ecil-4): guidelines for diagnosis, prevention, and treatment of invasive fungal diseases in paediatric patients with cancer or allogeneic haemopoietic stem-cell transplantation. Lancet Oncology. 2014, 15(8): e327-e340. DOI:10.1016/S1470-2045(14)70017-8

22. van Burik JA, Ratanatharathorn $V_{\text {, Stepan }} D E$, Miller CB, Lipton $J H$, Vesole DH et al. Micafungin versus fluconazole for prophylaxis against invasive fungal infections during neutropenia in patients undergoing hematopoietic stem cell transplantation. Clin Infect Dis. 2004; 39(10):1407-16). DOI:10.1086/422312

23. Huang $X$, Chen $H$, Han M, Zou P, Wu D, Lai Y et al. Multicenter, randomized, open-label study comparing the efficacy and safety of micafungin versus itraconazole for prophylaxis of invasive fungal infections in patients undergoing hematopoietic stem cell transplant. Biol Blood Marrow Transplant. 2012;18(10):1509-16. DOI: 10.1016/j.bbmt.2012.03.014

24. Hirata Y, Yokote T, Kobayashi K, Nakayama S, Oka S, Miyoshi T et al. Antifungal prophylaxis with micafungin in neutropenic patients with hematological malignancies. Leuk Lymphoma. 2010; 51(5):853-9. DOI:10.3109/10428191003682726

25. Hiramatsu Y, Maeda Y, Fujii N, Saito T, Nawa Y, Hara M et al. Use of micafungin versus fluconazole for antifungal prophylaxis in neutropenic patients receiving hematopoietic stem cell transplantation. Int J Hematol. 2008; 88(5):588-95. D0I:10.1007/s12185-0080196-y

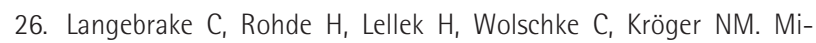
cafungin as antifungal prophylaxis in recipients of allogeneic hematopoietic stem cell transplantation: results of different dosage levels in clinical practice. Clin Transplant. 2014; 28(3):286- 91. DOI: $10.1111 /$ ctr.12310

27. De Pauw B, Walsh TJ, Donnelly JP, Stevens DA, Edwards JE, Calandra T et al. Revised Definitions of Invasive Fungal Disease from the European Organization for Research and Treatment of Cancer/Invasive. Clin Infect Dis. 2008;46(12):1813-21. DOI:10.1086/588660

28. Epstein DJ, Seo SL, Huang YT, Park JH, Klimek VM, Berman E et al. Micanfungin vesus posaconazole prophylaxis in acute leukemia or myelodysplastic sindrome: A randomized study. J. Infect. 2018; 77(3):227-2349. DOI:10.1016/j.jinf.2018.03.015

29. El-Cheikh J, Crocchiolo R, Vai A, Furst S, Bramanti S, Sarina B, et al. Comparison of three distinct prophylactic agents against invasive fungal infections in patients undergoing haplo-identical hematopoietic stem cell transplantation and post-transplant cyclophosphamide. Mediterr J Hematol Infect Dis 2015; 7. D0I:10.4084/ MJHID.2015.048

30. Lee $\mathrm{CH}$, Lin $\mathrm{JC}$, Ho CL, Sun M, Yen WT, Lin C. Efficacy and safety of micafungin versus extensive azoles in the prevention and treatment of invasive fungal infections for neutropenia patients with hematological malignances: A meta-analysis of randomized controlled trials. PLOS ONE 12(7):e0180050. DOI: 10.1371/journal. pone. 0180050 